\title{
STAKEHOLDER APPROACH AND THE CORPORATE FINANCIAL PERFORMANCE
}

\section{Ladislav Blažek, Ondřej Částek}

Ekonomicko-správní fakulta Masarykovy univerzity, katedra podnikového hospodářství, Lipová 41a, 60200 Brno (blazek@econ.muni.cz; castek@econ.muni.cz)

\begin{abstract}
The following paper aims to describe the analysis and utilization of stakeholder approach, which was used in the research of the Research Centre for Competitiveness of Czech Economy. The stakeholder model was employed in the research to explain the behavior of enterprises and to find factors of competitiveness. Here we can find assessment of stakeholders' importance and its relationship to corporate financial performance with some chosen interfering factors, which is preceding step before assessment all potential factors of competitiveness using multi dimensional analysis. Also the achieved results are related to chosen international and Czech studies.
\end{abstract}

Key words: Stakeholder approach, stakeholder model, empirical research, importance of stakeholders, corporate performance.

\begin{abstract}
Abstrakt: Předložený článek si klade za cíl popsat analýzu a využití stakeholderského přístupu, jenž byl aplikován při výzkumu Centra pro výzkum konkurenční schopnosti české ekonomiky. Úlohou stakeholderského modelu zde bylo vysvětlit chování podniků a pomoci najít faktory jejich konkurenceschopnosti. V článku nalezneme hodnocení důležitosti stakeholderů podniky a vyhodnocení vztahů důležitosti jednotlivých stakeholderských skupin k finanční výkonnosti podniků, a to včetně zahrnutí některých moderujících veličin. Tím je učiněn krok předcházející evaluaci všech potenciálních faktorů konkurenceschopnosti za použití vícerozměrné analýzy. Článek také nabízí ke komparaci výsledků srovnatelné zahraniční i české studie.
\end{abstract}

Klíčová slova: Stakeholderský přístup, stakeholderský model, empirický výzkum, důležitost stakeholderů, výkonnost podniku.

JEL classification: M10

DOI: $10.2478 / \mathrm{v} 10135-009-0002-7$

Národohospodářský obzor - Review of Economic Perspectives ISSN 1804-1663 (Online), ISSN 1213-2446 (Print)

http://nho.econ.muni.cz/en

(C) Masarykova univerzita 


\section{STAKEHOLDER APPROACH AND THE CORPORATE FINANCIAL PERFORMANCE}

\section{Ladislav Blažek, Ondřej Částek}

\section{Introduction}

Competitiveness of economies of particular countries or regions, i.e. competitiveness on the national level, is influenced to a great extent by competitiveness of individual companies. Competitiveness of a company can be seen as a potential which allows a company to succeed when competing with other companies. Using this potential well may lead towards a higher corporate financial performance. The reverse relation is equally true; high corporate financial performance may be the origin of its competitiveness.

Opinions on the main source of the competitiveness and high corporate financial performance have changed significantly over the last decades. During the times of a manufacturing boom in the middle of the last century the financial and capital assets were of primary importance. Later, in relation to rising demands on quality and innovation, and in addition to supply exceeding demand, importance of the non-capital assets started to grow. Toward the end of the $20^{\text {th }}$ century and nowadays in current turbulence, individualization, pursuit of high investments, growing differentiation of division of labor, and increased co-operation among companies often on global level, the creative work of a man becomes more and more important together with personal relationships within a company, and especially a company's relationship towards its surroundings.

The traditional shareholder concept regarding a company as a set of tangible things which one can own is continuously being replaced by a view of a company as a set of relationships. This conforms to the stakeholder concept of a company which regards a company as meeting of interests of the participants, called stakeholders who make a certain contribution to the relationship with the company and in exchange for it they expect certain gains.

The aim of this essay is to present results of analysis of influence of stakeholder importance on corporate financial performance.

\section{Developing stakeholder approach}

The origin of the stakeholder theory and the stakeholder approach derived from it, dates back to the 1960s. The first tracked usage of the word 'stakeholder' in the meaning we use here is from 1963. The word stakeholder was used in an internal memo at Stanford Research Institute and referred to 'such groups without whose support an organization would cease to exist' (Freeman, Reed, 1983, p.89).

However the basis typical for the stakeholder thinking can be tracked well before that. We can mention Mary Parker Follet who in her work from 1918 (Follet, 1918) expressed her convictions that the responsibility for the investigation of social problems and the implementation of their solutions should be passed from government institutions onto networks of other groups. 
Berle and Means (Berle, Means, 1932) are also important and frequently quoted authors. Apart from other things, they were concerned with the issue of whether corporations should be treated as important social institutions. During the process of so called 'managerial revolution' they favored the top management, the representatives of the big and powerful American companies, which they labeled 'corporation statesmen'. They saw the main goal of their work in balancing the interests of the shareholders, the employees and the American public. In 1938, Chester Barnard (Barnard, 1938) argued that the purpose of a company's existence is to serve society and that it is a manager's task to pass this sense of moral responsibility onto the employees.

The situation changes after 1963 thanks to the explicit definition of the term 'stakeholder'. In 1965, Igor Ansoff (Ansoff, 1965) admits in his book Corporate Strategy the existence of the stakeholder theory even though there is no mentioning of a publication from previous times which involves the theory. Yet at that time Ansoff refused the stakeholder theory and preferred the view that divides the aims of a company into economic and social, where the social ones are only 'secondary, modifying and limiting' the economical aims (Freeman, Reed, 1983, p. 89). According to Ansoff the following authors were of the same opinion: F. Abrams (Management Responsibilities in a Complex World, 1954) a R. M. Cyert s J. G. Marchem (A Behavioral Theory of the Firm, 1963).

Edward Freeman (Freeman, Reed, 1983) indicates that the development of the stakeholder theory in 1960s and at the beginning of the 1970s was slow. Apart from the continuing work at Stanford Research Institute almost no one was working on the advancement of the stakeholder approach. Eric Rhenman from Sweden was an important exception with his work Industrial Democracy and Industrial Management (Rhenman, 1968, cited from Freeman, Reed, 1983). Also in the same year Raymond Baumhart conducted a survey among higher management which showed that 80 per cent of them thought it non-ethical to focus uniquely on the owners' interests and not on the employees or the consumers.

What was the background to this development? From Yvone Pesquex and Salmy Damak-Ayadi's text it is obvious that during that time communities were growing stronger. For example in 1967 they criticized Eastman Kodak AGM because of racial tensions and high level of unemployment among black population in Cleveland and surroundings. Then in 1970 the consumers' association complained about the safety of General Motors cars and was also interested in social practices of this producer. Both cases together with many others generated a lot of media attention. During those times the public became more sensitive towards questions concerning the environment, such as air and water pollution, toxic waste etc. (Pesqueux, Damak-Aydi, 2005, p.7). Antiwar feelings and citizens' rights became frequent topics as well, (Sturdivant, 1979, p. 53).

In their article from 1978 Smith and Carroll (Smith, Carroll, 1978) pointed out the fact that unlike in previous times the above mentioned circumstances were influencing manager's work to a yet greater extent. To get a better image they compare the situation in which managers operated 40 years before, and they drew the conclusion that certain aspects of the situation were either not considered as problems or were not considered problems managers should be dealing with. They explicitly name environment, energetics, consumerism, health and safety, deceiving advertising, safety of goods. They 
stated that the aim of doing business had changed from the thorough maximization of profit to aims emphasizing long term existence of a company.

It is likely that thanks to these changes in business environment the interest in the stakeholder approach continued, even though the published works do not suggest so. The work Redesigning the Future by Russell Ackoff from 1974 is being quoted; in it Ackoff goes back to earlier works by Ansoff and 're-discovers' the stakeholder approach. He also argued that 'many social problems can be solved by the redesign of fundamental institutions with the support and interaction of stakeholders in the system' (Freeman, Reed, 1983, p.89).

Work in this area continued at the Stanford Research Institute and from 1977 also at Wharton Applied Research Center (WARC; facility of The Wharton School of the University of Pennsylvania). At WARC they dealt with application projects which lead to an article by Edward Freeman and David Reed (Freeman, Reed, 1983) and later to Freeman's monograph Strategic Management: A Stakeholder Approach (Freeman, 1984). Even though Freeman expected the usage of his work mainly, as the title suggests, in strategic management, he was surprised to learn that experts focusing also on business ethics or social responsibility of companies took an interest in it too.

Literature capturing the development of the stakeholder theory and stakeholder approach is quite vast. The above text does not claim to be a thorough analysis of the subject but to serve to illustrate the reasons why these strings of thoughts came into existence, and their diversity in the theoretical are. The practical application is explored further; we will summarize some landmark international and a few Czech researches.

\section{Summary of results of selected empirical investigations}

Allouche and Laroche (2005) in their research analyzed 82 studies focusing on the relation of corporate social and financial performance. With regard to the extent of these studies, we have selected the two most frequently quoted ones that will best help us to formulate hypotheses for our research. To these two foreign studies we also attach the results of researches from the Czech environment with which the authors are familiar. It is possible to use them too, if not for formulating the hypotheses, then at least for comparison of research designs and results.

\section{Research of Berman et al.}

Berman et al. set up the goal to verify the validity of the Strategic Stakeholder Management Model (The Direct Effects Model and The Moderation Model) and The Intrinsic Stakeholder Commitment Model (Berman et al., 493 - 494). To achieve this, they used a sample of companies from the list of the top hundred in Fortune 500 (for the year 1996), for which were provided complete financial data for the years $1991-1996$. The selected group consisted of 81 companies from various industries. Financial performance, as a dependent variable, was measured using ROA (operational result towards total assets). Stakeholder approach as an independent variable was expressed by actions of the researched enterprises towards five defined so-called stakeholder groups. These were the following: relationships with employees, diversity, community, natural environment and product safety/quality. 
The way in which they controlled for the moderating effect of industry is interesting. Its impact was involved using three variables: dynamism, munificence, concentration. The first two variables were measured by gross product of the companies, the last by the sales of four leading firms divided by total industry sales.

This research proved the direct impact of variables identified as employees and safety and quality of products on corporate financial performance. For the remaining three variables, this impact was not observed in spite of the fact that the previous researches implied it (Robinson and Dechant, 1997; Waddock and Graves, 1997). Berman et al. offer an explanation that the variable communities and diversity, which are important mainly in normative regard, can not in an isolated way affect financial performance. In the case of the environment variable, its impact could be limited by the fact that the researched companies derived from various industries, in which the importance of the environment and form of environmental care can have different forms and impacts on financial performance. Another limiting effect could be the location of the companies that was not controlled for.

Whereas the direct impact was observed only in two variables, in the moderated model of strategic stakeholder management all the five variables influenced the strategy financial performance relation. It is thus shown that the causal relation between the relationships with stakeholders and financial performance is substantially more complicated and can not be reduced only to the level of the relationship with a particular stakeholder - financial performance.

As opposed to the models of strategic stakeholder management, the model of inherent stakeholder commitment was not confirmed in this research. It did not apply therefore in the researched enterprises that the relations with stakeholders would influence the formulation of strategy for normative reasons. Berman et al. propose here the possibility for further research to include values and motivations of managers in the model.

The important conclusion for us is that the dependence of financial performance on the relationships to particular individual stakeholders was proved, but furthermore that this dependence can not be fully explained in the isolating of these relationships, but must be examined in mutual context. Another proved fact is the importance of industry effect.

\section{Preston and O'Bannon's research}

This study (Preston, O'Bannon, 1997) is interesting due to the fact that it examines not only the existence of the dependence between corporate financial and social performance alone and its direction (i.e. whether the dependence is positive or negative), but also causality. The statistic tools alone can only ensure the direction of dependence, i.e. whether the higher social performance is associated with higher or lower financial performance. It is however incapable of disclosing whether the social performance causes the financial performance or vice versa. This issue must therefore be solved already in the stage research design.

The selected sample consisted of 67 enterprises whose necessary data were collected for the period from 1982 to 1992 inclusively. It monitored, on the side of social performance, the relationship of enterprises to these stakeholder groups: communities, employees and customers. The data to evaluate these relationships were obtained from the database of Fortune Magazine, which since 1982 has monitored the reputations of 
several thousands of top managers and analytics of the biggest enterprises in many businesses. ROA, ROE and ROI indicators were used for evaluation of the financial performance.

Apart from examining the causality, Preston and O'Bannon focused also on the direction of dependence. None of the 270 calculated correlations was negative, i.e. no result proved the possibility of the direction of dependence that higher social performance is associated with lower financial performance (or lower social performance with higher financial performance).

Regarding the causality, the highest correlations were achieved if the financial performance (ROA in this case) of the year $n$ was compared with the social performance of the year $n+1$. The intensity of dependence achieved here up to 0.6410 (with expressing the social performance by the quality of relationships with the employees) and the result thus indicates that the higher the financial performance, the higher the social performance (so-called hypothesis of available financial means). This is proven also by the fact that in 30 triads of results (dependence of the amount of ROA on the quality of relationships with individual groups in the individual years), the dependence of the quality of relationship on ROA was 16 times the strongest in these triples. In the remaining 14 triads, the dependence of ROA and social performance in the same year was the strongest, which does not imply which variable is dependent on which. This coaction achieved the intensity of up to 0.6019 (again interrelation between the quality of relations with the employees and ROA). The dependence of ROA on the social performance was not the strongest one in any of the triads. This type of dependence achieved the strongest result of 0.5172 (again interrelation between the quality of relations with employees and ROA), which is by an entire fifth worse than the result of the inverse causality.

\section{Research of the "Management of Relationships with Stakeholders at Industrial Markets in the Context of Current Marketing Concepts"}

This research was conducted by Šimberová (2008) within her inaugural dissertation. The goal was to "create a methodology of coordination and mutual interconnection of marketing and business activities via tools of management of relationships with stakeholders based on the most recent theoretical and empirical knowledge" (Šimberová, I. 2008, p. 5).

The respondents from the sample of 60 Czech enterprises in the area of production, services and business were supposed to respond to the question as to what the importance of the individual stakeholders is to succeed on the market, on a scale ranging from 1 - minimum impact - up to 10 - key effect on the company success. The order was the following: customers, employees, management, owners, suppliers, financial institution, competition, academic centers, local administration bodies, State administration bodies, consulting companies, citizens, economic or business chamber, innovation centers (Šimberová, I., 2008, p. 17).

\section{Research of "Communication with the Stakeholders as a Factor of competitiveness of the enterprise"}

This research was conducted by Medek for his doctoral dissertation thesis. Apart from others, he outlined a goal "to define the interest groups that are influenced by the 
company activities or that influence them with their behavior, and their division in groups according to actions and importance" (Medek, M., 2006). 178 enterprises were approached with the questionnaire return ratio of $23 \%$. The results of the importance of communication with the individual groups of stakeholders were the following: customers, employees, suppliers, shareholders, expert press, bodies and institutions of public administration, other media, investors, trade unions, schools and universities, competitors, former employees, financial analysts, political circles, interest groups in the neighborhood, family members of the employees, associations of consumers (Medek, M., 2006, pp. 86 - 93).

The results were also evaluated separately according to the size of the companies. Interesting is the fifth spot of suppliers in the largest companies, whereas their average ranking among all the companies was third place. This means that the importance of the supplier in these large companies is significantly lower than in other companies. The situation is different in the importance of trade unions, which on average ranked ninth, but third in the case of the largest companies.

Certain trends of correlation between the size of the company and importance of some groups can be monitored for the following groups:

- the increase of importance with the growth of the size of enterprise: the employees, authorities and institutions of public administration, trade unions, schools and universities, financial analysts,

- decrease of importance with the growth of the size of enterprise: suppliers, shareholders, investors, competitors, family members of the employees, associations of consumers.

In the underlined groups the trend is more distinct. The groups are classified according to the total importance of communication with them. The importance of communication can not be mistaken for the importance of these groups; it can however imply something about it.

\section{Summary}

The number of researches dedicated to the issues of stakeholder approach is significantly lower in the Czech Republic than abroad. Our list is naturally not complete, we can also mention the researches of Blažek et al. (2004) Development tendencies of enterprises, or Czech-Austrian research Aktion (Theodor, M., 2004). Blažek et al., however, did not verify their conclusions on empirical data and the only relevant conclusion for us from the Aktion research is that "most of the managers of the interviewed enterprises did not know the term stakeholder".

Based on the presented Czech researches, we can derive the conclusion that they ascertained the importance of the individual stakeholder groups but they did not in any way relate it to the performance of the enterprise, defining of the individual stakeholder groups was not provided with reasoning in any case and the generalization potential of the given investigations is due to the very low samples used (in the Aktion research, the number of enterprises was only 40, in most of them, however, only half of the necessary data were obtained). 
It is possible to state that in the Czech Republic there is an apparent absence of sufficiently representative analyses of the stakeholder approach and the influence of stakeholders on corporate financial performance. This fact led the authors of the article to use, for the purposes of evaluation of the relationship between the individual groups of shareholders and corporate financial performance, results from the Empirical survey of Czech corporate competitiveness conducted within the Research Centre for Competitiveness of Czech Economy, operating at the Faculty of Economics and Administration of the Masaryk University.

\section{Brief characteristics of empirical survey of corporate competitiveness}

The empirical investigation of the competitiveness of companies residing in the Czech Republic was, after an extensive methodological preparation, conducted in the year 2007.

The basic set of the investigated companies was defined according to the following:

a) territorial aspect - companies with a seat in the Czech Republic;

b) industry aspect - companies belonging to the section $\mathrm{C}$ to $\mathrm{K}$ of the Business Classification of economic activities of the Czech Statistical Office (hereinafter referred to as OKEČ);

c) size aspect - companies with a number of employees of 50 and more;

d) aspect of legal form - joint stock companies or limited liability companies.

The group of companies that meet the above criteria, after exclusion of companies in bankruptcy proceedings or with information about filing of bankruptcy or Court execution, consisted of 7396 subjects at the time of the empirical survey.

With regard to the available capacities, the empirical survey led to the fact that wide business structure was reduced to two industries only that, however, form the core of the national economy, i.e. to $\mathrm{D}$ - Processing industry and $\mathrm{F}$ - Construction industry. In the time of the empirical survey, 4483 enterprises fell within these businesses, which is more than $60 \%$ of the businesses falling within the above set.

With regard to the capacity possibilities and in respecting the reasonable level of representativeness, the size of the sample was set at 450 enterprises, which represents approximately $10 \%$ of the above described population.

With regard to the fact that the information about the companies necessary for subsequent analysis was obtained not only from the questionnaire (used in the survey), but also from the Albertina Data database, it was necessary, in the selection of the companies where the questionnaire investigation was to take place, to analyze as well to what extent and in what quality the necessary information is available in this database. On the basis of this analysis, 2817 enterprises were selected, which achieved the required level in terms of complexity and quality of accounting information.

Two basic information sources were selected for the empirical investigation:

a) publicly disclosed information;

b) information from questionnaire.

The following information was especially used from the publicly disclosed information: 
- information from corporate web pages;

- $\quad$ analyses published on ipoint.financninoviny.cz website;

- information from the commercial register published on portal.justice.cz website;

- information from CreditInfo database constituting a part of the Albertina Data database.

Information from the Albertina Data database registers financial data compiled on the basis of annual financial statements. The set of data per company includes approximately 250 items. This information was, together with additional information from other sources of information, used for evaluation of corporate financial performance.

The questionnaire was designed in such a manner as to map the corporate characteristics in the most complex way possible and so as to be able to be completed realistically by an enquirer with special training within the interview with the respondent representative of the company. Despite attempts at conciseness and minimization of the extent, the monitored volume of information specified in the questionnaire was immense. The data items per one company equaled almost 800 (including approximately 300 items from publicly disclosed information). The empirical investigation was attended by a total of 432 companies, which is $15.33 \%$ of the population.

\section{Defining stakeholder groups}

One of the questions of the aforesaid questionnaire examined how the respondents perceive the importance of individual stakeholders. To formulate this question, it was necessary to find and to justify the structure of these interest groups.

Within the methodological preparation, an analysis of existing approaches published in reputable expert resources was conducted for this purpose. This analysis leaned especially on the summarizing publication of Mitchell et al. (1997). The analysis implied that the authors usually consider the stakeholders as the owners, employees and customers, which include both retail consumers as well as direct customers. They mostly agree also on the suppliers and creditors. The State is usually accepted but still discussed. Local communities, interest organizations, media and competition are considered problematic and not accepted by all the authors.

The structure of the interest groups applied in the above empirical investigation was formulated with regard to the results of this analysis. Strings of thoughts of institutional economy relating to corporate governance and perceiving the company as a group of contractual relations were also taken into account (Mlčoch, L., 2005, p. 99). The researchers took care to define the interest groups clearly and in a graspable way. The goal was also, to clearly, theoretically, and justifiably specify the expectation and power of the individual stakeholders. The stakeholder was defined as a legal subject (legal or physical entity) that, on the basis of legal regulation or contractual relation, provides the company with a certain contribution while expecting some value in return from the company. Seven stakeholder groups were formulated for the purposes of the research with respect to this definition: owners, employees, creditors, suppliers, customers, State and communities in proximity to the company. 


\section{Perception of stakeholders in the Czech Republic}

Some authors in the field of stakeholding try to prove (so called instrumental use of stakeholder theory) that if management focuses not only on owners, their financial performance could be higher. We can name Berman et al.(1999), Harrison and Fiet (1999), Luoma and Goodstein (1999), Ogden and Watson (1999), Agle et al. (1999) for example. The shareholder approach disputes and argues that only orientation on shareholder value contributes to financial performance. Other sources label customers as the most important group etc. Because most of this research has been carried out in the US, we have decided to check whether their results are valid in the Czech Republic. It was therefore necessary to analyze, how top managers of Czech companies perceive the stakeholders and how they assess their importance. Therefore these hypotheses were set:

H1. The higher is the importance of a particular stakeholder group, the higher is the corporate financial performance.

The empirical survey of the companies' competitiveness realized by the Research Centre for Competitiveness of Czech Economy (Blažek et al., 2007, Blažek, et al., 2008) investigated what importance generic stakeholder groups have. Within the questionnaire there was a question asking respondents to identify the importance of offered stakeholder groups: "Indicate the importance of stakeholder groups mentioned below for your company". It was answered on the scale from 1 - an unimportant stakeholder group - to 5 - highly important stakeholder groups for the current state; past and estimated future development (trends) were also indicated as increasing, stagnating or decreasing. Answers were entered separately for offered groups (owners, employees, creditors, suppliers, customers, the State, and communities in a company's environment). There were seven groups to choose because of splitting the group "State" into "State" and "communities in a company's environment."

The following figure shows the mean values of importance of the defined stakeholder groups. 
Fig. 1: Importance of the defined stakeholder groups

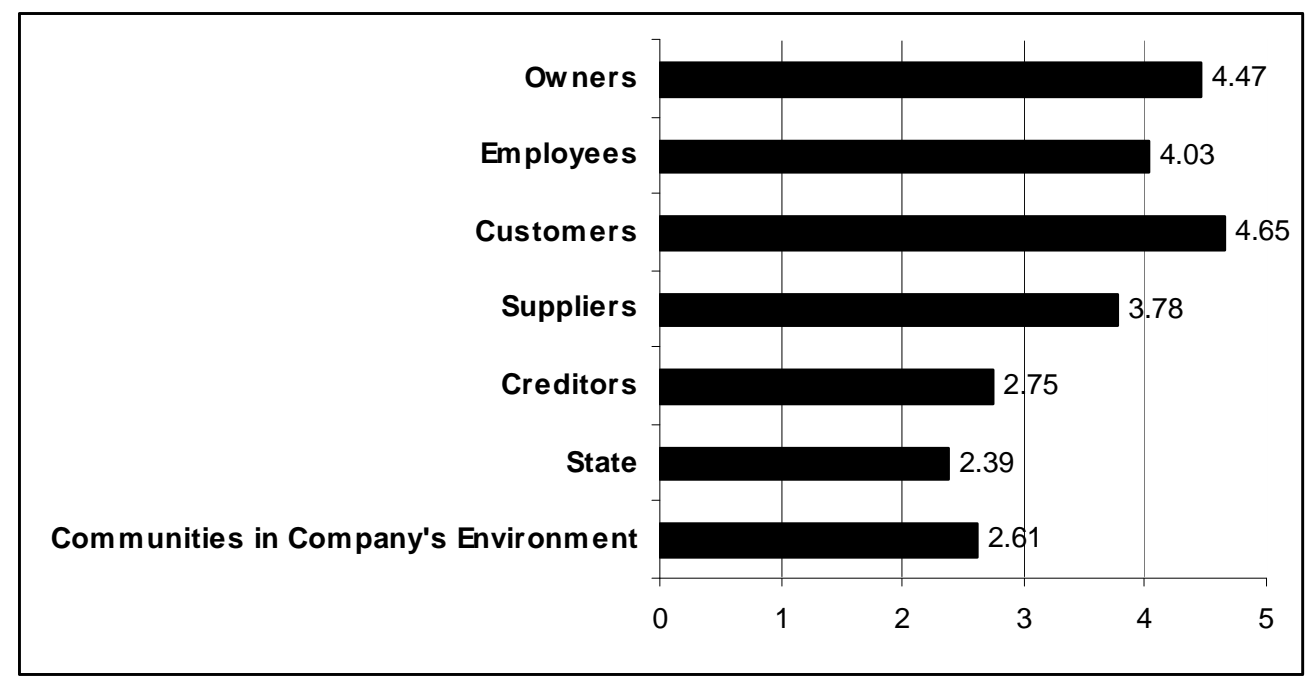

Source: Blažek, 2007, p. 25

Variables obtained from this question can be handled as ordinal; variables identifying the current state as a quasi interval and trends as nominal too. All of the variables had a very high return rate, higher than the rest of the questionnaire. The percentage of missing values was less than $1.6 \%$. A group of creditors represented an exception where the figures of missing values were $4 \%$. This can be interpreted in the way that creditors are not perceived as a separate interest group in some companies.

The highest importance was given to customers with mean achieving 4.65 . They were followed by owners (4.47), employees (4.03) and suppliers (3.78). Importance of creditors (2.75) has significantly declined since many companies depended on credits in the past. Respondents perceive the importance of the State as low (2.39), sometimes they do not even admit its importance at all, while the influence of state economic policy realized through legislation is undeniable. Probably the same impact of legislation on all companies is the reason why the companies' representatives feel the State importance as irrelevant. Also, they might have resigned themselves to the possibility to enforce their views and interests in the economic policy designing. Nevertheless, as we can witness later, this conclusion does not apply to all scrutinized companies. A little bit higher is importance of communities in the companies' environment (2.75), where in many cases respondents declared mutually beneficial cooperation with the municipality.

In accordance with the above mentioned premises dependencies between importance of separate stakeholder groups and corporate financial performance were tested, including tests of other variables' (drawn from other parts of the questionnaire) influence.

\section{Results}

Here will be assessed the hypotheses set. Effect of moderators is examined wherever can be expected and data are available. Statistical methods and actual correlation 
coefficients values and statistical significance can be found in Částek, 2009. The corporate financial performance was classified used cluster analysis based on two indicators: return of assets and rate of growth of assets. This is argued more in detail in L. Siska's paper (Šiška, 2008, pp. 7 - 9). We should remark here, that there were used figures from years $2002-2006$ to eliminate distortion because of the tax optimization etc. Also to respect progress, the values were weighted this way: year 2002 got weight 1 , 2003 got 2 and so on to 2006 with weight 5 .

The relationship between importance of owners and corporate financial performance is weak in whole sample, $\mathrm{G}=0.15$ (Goodman-Kruskal's Gamma) at $\alpha=0.04$. The cause may be due to different directions of the relationship in processing and construction industries. Whereas in processing industry it was found that the more important the owners are, the lower is the corporate financial performance $(G=-0.2$ at $\alpha=0.005)$, which might be an argument for supporters of stakeholder orientation, in construction industry it was found, that the more important the owners are, the higher the financial performance is $(\mathrm{G}=+0.2$ at $\alpha=0.18)$. The statistical significance is low in the construction industry, but size of this subset is only $\mathrm{N}=83$. It will be necessary to look for an explanation in case studies about representative companies.

Other noticeable result is that much stronger relationship with financial performance was found among the companies with one major owner $(G=-0.2$ at $\alpha=0.033)$, than among the companies with more owners without a major one $(G=-0.015$ at $\alpha=0.058)$. Both of these had the same direction, though. It can be explained by the fact that one major owner is more effective in decision making or setting strategy.

Also stock companies had this relationship stronger $(\mathrm{G}=-0.32$ at $\alpha=0.01)$ than limited companies $(\mathrm{G}=-0.14$ at $\alpha=0.18, \mathrm{~N}=240)$. Because it is common in the Czech Republic that in limited companies the owners participate in managing the company while in stock companies the management is elected more likely on the base of its abilities, this may indicate that the way of managing company is better among stock companies.

Companies, which are not a part of a concern, had the examined relationship about twice as strong $(\mathrm{G}=-0.3$ at $\alpha=0.016)$ as in the whole sample. That would mean that non-concern owners are better owners than concerns and if they are granted higher importance (in decision making etc.) the corporate financial performance is higher.

The relationship between importance of employees and performance is in the sample again weak $(\mathrm{G}=-0.1$ at $\alpha=0.08)$. However some authors and approaches point out that employees (or their knowledge) are crucial for a company or refer to the knowledge as to most important production factor, it hasn't proved to be likely in this analysis. But what must be taken into account is structure of explored sample. It consists of construction and processing industries and none of them are representatives of postindustrial society or so called knowledge economy.

A surprise could be that there was no relationship between customers' importance and financial performance. The most probable reason is that customers were assessed by informants as highly important or important in $87 \%$ of cases. Therefore there were no significant differences between better or worse performing companies. 
Statistically significant relationships were found in stock companies $(\mathrm{G}=-0.26$ at $\alpha=$ 0.06), large companies (250+ employees: $\mathrm{G}=-0.2$ at $\alpha=0.085)$ and companies exercising cost leadership strategy $(G=-0.3$ at $\alpha=0.02)$. Because no statistically significant relationship was found out in the whole sample, we cannot draw conclusions from these findings.

For suppliers' importance wasn't found statistically significant relationship in the whole sample as well and in subsets only for large companies $(\mathrm{G}=0.22$ at $\alpha=0.05)$ and stock companies $(\mathrm{G}=0.22$ at $\alpha=0.08)$.

Remarkable is the trend, which is opposite to the assumed one. The greater the importance of suppliers the lower is the corporate financial performance. This can be interpreted that if the company has low bargaining power, it has consequences for its financial performance. Higher importance of suppliers then indicates this relatively low bargaining power.

The situation is similar for creditors but here are crosstabs statistically significant at $\chi^{2}=0.109$. Again it can be explained with this causality: low financial performance means problems in acquiring finances (and higher need of it) and hence results in higher importance of creditors. In other words, if the company is in difficulties, the creditors are important to it. This is confirmed by Suchánek and Špalek (2009) who analyzed separately the least successful companies (cluster C). The importance of creditors as stakeholder group is actually one of the 20 factors of un-competitiveness.

Relatively strong is this relationship in construction industry $(\mathrm{G}=0.3$ at $\alpha=0.056)$ and among companies with $50-99$ employees $(G=0.29$ at $\alpha=0.019)$. In the Czech Republic many construction companies have problems with financing and are considered in general as more venturesome. Also smaller companies have worse position when obtaining loans.

State's importance seems to be in relationship with financial performance, but this relationship is weak in whole sample $(\mathrm{G}=-0.16$ at $\alpha=0.01)$. It is stronger in stock companies $(\mathrm{G}=-0.16$ at $\alpha=0.034)$ than in limited companies $(\mathrm{G}=-0.1$ at $\alpha=0.09)$ and in larger companies (100+ employees: $G=-0.2$ at $\alpha=0.03)$ than in small companies (50 - 99 employees). This may be caused by a higher possibility to influence authorities (lobbing) than small companies have. Statistically significant dependence was found also in processing industry $(G=-0.16$ at $\alpha=0.014)$.

Importance of communities in company's environment is in relationship with its financial performance, but it has an unusual form in the whole sample. The importance is about the same level in the best and worst companies and is declining in middle companies. The differences in means are statistically significant at $\alpha=0.001$ (three clusters) to $\alpha=0.043$ (five clusters) and crosstabs at $\chi^{2}=0.09$. Correlations are not statistically significant.

This might be explained by high importance of community among better companies because these companies can afford to address needs of communities, and a high importance of communities in worse companies results from the problems of these 
companies (e.g. pollution) which are these companies not able to solve and which have an impact on the communities.

There were also found opposite trends in the construction industry (growth of importance with growth of financial performance) and processing industry (growth of importance with decline of financial performance in the processing industry). However, these were not statistically significant.

\section{Conclusion}

Chosen stakeholder structure allows observing and considering behavior and decisionmaking of the company at the market of goods and services, labor market and market of capital. It pictures also the specific position of State.

This integral view of stakeholders operation at different markets constitutes background for optimization of balancing their interests. This way strategic management obtains a tool for realization of complex strategic analysis and following strategy making.

The results of the empirical survey indicate that top managers perceive the influence of stakeholders on competitiveness and corporate financial performance. However, importance of individual generic stakeholder groups is perceived in rather various ways.

The relationship between the stakeholder approach (measured by mean importance of chosen stakeholders) and financial performance proved to be true, but rather weak. It was stronger in larger companies and stock companies; these companies have probably better possibilities in addressing larger sets of stakeholder groups.

The authors are well aware of the limited validity of the results obtained. These limits derive from the fact that the analyzed effect was only that of the selected factors (i.e. importance of the individual stakeholders) and the impact of a series of other potential factors was left out of the account. The analysis designed in this way is legitimate only providing the validity under ceteris paribus condition which, however, is not and can not be met in corporate practice. Together with the action of the investigated factors, in reality the financial performance of each company is influenced by a series of other factors recruited from its internal and external environment. These factors can modify, mediate or even negate the effect of the factors monitored by us in various ways.

The presented analysis is therefore a partial analysis only. It corresponds to the used statistical method, which is not able to test, with the given size of the selection group, more than three or four variables. The given analysis constitutes a part of the entire set of partial analyses testing the partial effects of the individual groups of potential factors on corporate financial performance. These analyses were conducted within the abovementioned research on the competitiveness of Czech companies. They, however, form only the first, but necessary step on the way towards more advanced analyses. It should verify the validity of the hypothesis that there is a significant dependence between a certain type of corporate financial performance and certain typical configuration of the values of partial factors. This task, however, requires the application of multidimensional statistical analysis to evaluate the effects of various combinations of a high number of the potential factors. Methodological preparation and the first results of these works are published in the monograph by Blažek et al. 2008. 


\section{References}

AGLE, B. R., MITCHELL, R. K., SONNENFELD, A. J. (1999). Who matters to CEOs? An investigaiton of stakeholder attributes and salience, corporate performance, and CEO values. Academy of Management Journal, 42(5), pp. 507-525. ISSN 00014273.

ALLOUCHE, J., LAROCHE, P. (2005). A meta-analytical investigation of the relationship between corporate social and financial performance. Revue de Gestion des Ressources Humaines. 57, pp. 18-41.

ANSOFF, I. (1965). Corporate Strategy. New York: McGraw-Hill.

BARNARD, CH. (1938). The Function of the Executive. London: Harvard University Press. ISBN 0-674-32803-5.

BERLE, A., MEANS, G. (1932). The Modern Corporation and Private Property. New York: Macmillan.

BERMAN, S., WICKS, A., KOTHA, S., JONES, T. (1999). Does stakeholder orientation matter: The relationship between stakeholder management models and firm financial performance. Academy of Management Journal, 42(5), pp. 488-506. ISSN 00014273.

BLAŽEK, L. (2005). Výzkum konkurenceschopnosti podniku. Aplikace stakeholderského př́stupu. In Vývojové tendence podniků. Vol. 1, pp. 13-28. Brno: Masarykova univerzita. ISBN 80-210-3847-0.

BLAŽEK, L. (2007). Dílčí závěry z empirického šetření konkurenceschopnosti podniků. Working Paper č. 31/2007. Brno: Masarykova univerzita, CVKS. ISSN 1801-4496.

BLAŽEK, L. et al. (2007). Konkurenční schopnost podniků: (primární analýza výsledků empirického šetření). 1. vyd., Brno: Masarykova univerzita, 2007. ISBN 9788021044562.

BLAŽEK, L. et al. (2008). Konkurenční schopnost podniků: (analýza faktorů hospodářské úspěšnosti). 1. vyd., Brno: Masarykova univerzita. ISBN 9788021047341.

BLAŽEK, L., ČADA, R., GOLEC, R., KUBÁTOVÁ, E., ŠIŠKA, L. (2004) Vývojové tendence podniků. Část 1. Závěrečná zpráva výzkumného úkolu. Brno: Masarykova univerzita, Ekonomicko-správní fakulta, 2004. Internal source

BOHATÁ, M. (1998). Teorie zájmových skupin-možnosti a limity. Politická ekonomie. 5/1998, Praha: Vysoká škola ekonomická. pp. 733-741. ISSN 0032-3233.

ČÁSTEK, O. (2009) Tvorba hodnoty v dodavatelsko-odběratelských vztazích a její typy. In Hradecké ekonomické dny 2009. Ekonomický rozvoj a management regionů. 1. vyd. Hradec Králové: Gaudeamus, Univerzita Hradec Králové, 10 p. ISBN 978-0-7041-2275.

DONALDSON, T., PRESTON, L. E. (1995) The stakeholder theory of the corporation: Concepts, evidence, and implications. Academy of Management Review. 20(1), pp. 6591.

FOLLETT, M. P. (1920). The New State: Group Organization the Solution of Popular Government. London.

104 
FREEMAN, R. E. (1974). Strategic management: A stakeholder approach. Boston: Harper Collins.

FREEMAN, R. E., REED, D. L. (1983). Stockholders and stakeholders: A new perspective on corporate governance. California Management Review, 25(3), pp. 93-94.

HARRISON, J., FIET, J. (1999) New CEOs pursue their own self-interest by sacrificing stakeholder values. Journal of Business Ethics. 19/1999, pp. 301-308. ISSN 0167-4544.

HUČKA, M. et al. (2007) Správa společností. Praha: Kernberg Publishing, s.r.o., ISBN 978-80-903962-0-3.

LUOMA, P., GOODSTEIN, J. (1999). Stakeholders and corporate boards: institutional influences on board composition and structure. Academy of Management Journal, 42(5), pp. 553-563. ISSN 00014273.

MEDEK, M. Komunikace se skupinami stakeholders jako faktor konkurenceschopnosti podniku: disertační práce. Zlín: Univerzita Tomáše Bati ve Zlíně, 2006, 226 s.

MITCHELL, R. K., AGLE, B. R., WOOD, D. J. (1997). Toward a theory of stakeholder identification and salience: Defining the principle of who and what really counts. Academy of Management Review, 22(4), pp. 853-886.

MLČOCH, L. (2005). Institucionální ekonomie. Praha: Karolinum. ISBN 8024610299.

OGDEN, S., WATSON, R. (1999). Corporate performance and stakeholder management: balancing shareholder and customer interests in the U.K. privatized water industry. Academy of Management Journal, 42(5), pp. 526-538. ISSN 00014273.

PESQUEUX, Y., DAMAK-AYADI, S. (2005). Stakeholder theory in perspective. Corporate Governance. 5(2), pp. 5-21. ISSN 1472-0701.

PRESTON, L. E., O'BENNON, D. P. (1997). The Corporate Social-Financial Performance Relationship. Business and Society. 36/1997, pp. 419-426.

RHENMAN, E. Industrial Democracy and Industrial Management. London: Tavistock, 1968. $188 \mathrm{~s}$.

ROBINSON, G., DECHANT, K. (1997). Building a business case for diversity. Academy of Management Executive. 11/3/1997, pp. 21-31.

SMITH, H. R., CARROLL, A. B. (1978). Is There Anything „New“ in Management? A „Rip Van Winkle“ Perspective. Academy of Management: The Academy of Management Review.

STURDIVANT, F. (1979). Executives and Activists: A Test of Stakeholder Management. California Management Review. pp. 53-59.

SUCHÁNEK, P., ŠPALEK, J. (2009). Competitiveness of Czech Enterprises: Why The Enterprise Is Less Successful? Národohospodářský obzor. 9(2), 107-120. ISSN 12132446. 2009. DOI: 10.2478/v10135-009-0003-6

ŠIMBEROVÁ, I. Rízení vztahů se stakeholdry na průmyslových trzích v kontextu současných marketingových koncepcí. Vědecké spisy vysokého učení technického v Brně. Sv. 251. 38 s. ISSN 1213-418X. 
ŠIŠKA, L. (2008). Analýza finanční výkonnosti respondentů empirického šetření CVKS. Working paper 10/2008. Brno: Centrum výzkumu konkurenční schopnosti české ekonomiky. ISSN 1801-4496.

THEODOR, M. (2004). A Stakeholder Approach to Measuring the Level of Corporate Governance. Acta Oeconomica Pragensia. 5/2004. pp. 30-37.

WADDOCK, S. A., GRAVES, S. (1997) The Corporate social performance-financial performance link. In Strategic Management Journal. 18/1997, pp. 303-317.

\title{
STAKEHOLDER APPROACH AND THE CORPORATE FINANCIAL PERFORMANCE
}

\section{Ladislav Blažek, Ondřej Částek}

Ekonomicko-správní fakulta Masarykovy univerzity, katedra podnikového hospodářství, Lipová 41a, 60200 Brno (blazek@econ.muni.cz; castek@econ.muni.cz)

\begin{abstract}
The following paper aims to describe the analysis and utilization of stakeholder approach, which was used in the research of the Research Centre for Competitiveness of Czech Economy. The stakeholder model was employed in the research to explain the behavior of enterprises and to find factors of competitiveness. Here we can find assessment of stakeholders' importance and its relationship to corporate financial performance with some chosen interfering factors, which is preceding step before assessment all potential factors of competitiveness using multi dimensional analysis. Also the achieved results are related to chosen international and Czech studies.
\end{abstract}

Key words: Stakeholder approach, stakeholder model, empirical research, importance of stakeholders, corporate performance.

\begin{abstract}
Abstrakt: Předložený článek si klade za cíl popsat analýzu a využití stakeholderského přístupu, jenž byl aplikován při výzkumu Centra pro výzkum konkurenční schopnosti české ekonomiky. Úlohou stakeholderského modelu zde bylo vysvětlit chování podniků a pomoci najít faktory jejich konkurenceschopnosti. V článku nalezneme hodnocení důležitosti stakeholderů podniky a vyhodnocení vztahů důležitosti jednotlivých stakeholderských skupin k finanční výkonnosti podniků, a to včetně zahrnutí některých moderujících veličin. Tím je učiněn krok předcházející evaluaci všech potenciálních faktorů konkurenceschopnosti za použití vícerozměrné analýzy. Článek také nabízí ke komparaci výsledků srovnatelné zahraniční i české studie.
\end{abstract}

Klíčová slova: Stakeholderský přístup, stakeholderský model, empirický výzkum, důležitost stakeholderů, výkonnost podniku.

JEL classification: M10

DOI: $10.2478 / \mathrm{v} 10135-009-0002-7$ 